九州大学学術情報リポジトリ

Kyushu University Institutional Repository

\title{
Impact of Different Comb Age on Morphological and Biological Characteristics of Honeybee Workers (Apis Mellifera L.)
}

SHAWER, Mohamed B.

Department of Economic Entomology, Faculty of Agriculture, Kafrelsheikh University

ELNABAWY, Elsaid M.

Department of Economic Entomology, Faculty of Agriculture, Kafrelsheikh University

MOUSA, Kareem M.

Department of Economic Entomology, Faculty of Agriculture, Kafrelsheikh University

GABER, Sahar

Department of Economic Entomology, Faculty of Agriculture, Kafrelsheikh University

他

https://doi.org/10.5109/4103891

出版情報 : 九州大学大学院農学研究院紀要. 65 (2)，pp.277-282，2020-09. Faculty of Agriculture， Kyushu University

バージョン :

権利関係 : 


\title{
Impact of Different Comb Age on Morphological and Biological Characteristics of Honeybee Workers (Apis Mellifera L.)
}

\author{
Mohamed B. SHAWER ${ }^{1}$, Elsaid M. ELNABAWY', Kareem M. MOUSA ${ }^{1}$, \\ Sahar GABER ${ }^{1}$ and Takatoshi UENO*
}

\begin{abstract}
Laboratory of Insect Natural Enemies, Division of Biological Control, Department of Applied Genetics and Pest Management, Faculty of Agriculture, Kyushu University, Fukuoka 819-0395, Japan (Received May 22, 2020 and accepted May 27, 2020)
\end{abstract}

\begin{abstract}
A variety of environmental and physiological factors are involved in honeybee health and honey yields. The aim of this study is to assess the impact of wax comb age on the morphological and biological characteristics of honeybee workers and their relationship with comb morphology and honey production. For this purpose, we used combs with different age ranging from new ( 0 year old) to 7 years old. The results revealed that hexagonal cell volume, inner cell diameter, etc., significantly became smaller with increasing comb age. As the consequence, honeybee workers produced from older combs significantly had a lighter body weight, shorter proboscis, smaller tibia, tarsus and forewings. Also, the sizes of mandibular glands, hypopharyngeal glands, and second wax glands were significantly decreased when bees were emerged from older combs. However, the exuvium and wax weights, and the height of hexagonal cell base were significantly greater in older combs. Furhter, comb age had a significant impact on brood rearing; worker and drone brood areas were smaller in older combs. Finally, total honey yields were found to decrease significantly with increasing comb age. The present study thus highlighted the importance of comb age management in maintaining honeybee health and maximizing honey production.
\end{abstract}

Key words: comb management, wax comb, beekeeping, honey yield, apiaries.

\section{INTRODUCTION}

The honeybee Apis mellifera L. in nature constructs the nests in protected places like stone caves or tree holes, and the available size or space in such protected places can determine the number and size of combs, which can reflect the size of honeybee colonies (Seeley, 1985; Winston, 1991). In the domesticate honeybees, comb management is a common practice for beekeepers because it is important to maximize honey production. Framed combs are added or replaced to balance the health of honeybee colonies and their production, as well as to produce many generations of honeybees.

Although there are many factors affecting honey production and honeybee health, comb feature is an important determent. One of the major features of honeybee comb that may influence honey production and honeybee health can be the age of combs (Berry and Delaplane, 2001; Dizaji et al., 2008). The color of comb when first constructed is nearly white and malleable, and the cells have a circular shape at birth (Karihaloo et al., 2013). The comb becomes more fragile and more tenuous with comb age (Hepburn and Kurstjens, 1998). Although the color of honey combs remains relatively unchanged, the color of brood combs turns into dark brown as the time passes, which is resulted from a large number of contaminants absorbed in the wax over time (Taha and El-Sanat, 2007). Some of the contaminants

${ }^{1}$ Department of Economic Entomology, Faculty of Agriculture, Kafrelsheikh University, Elgeish Street, Kafrelsheikh 33516, Egypt

* Corresponding author (E-mail: ueno@grt.kyushu-u.ac.jp) are fungal and bacterial spores, pesticides and heavy metals (Berry and Delaplane, 2001). Also, older brood combs are more likely to contain hive debris and to have thicker propolis layers, which makes them darker colored (Koenig et al., 1986).

In addition, the diameters of the cells become narrow as the comb age increases because of the accumulation of silks and fecal materials produced by the developing larvae (Hepburn and Kurstjens, 1988). As time passes with successive generations of honeybee, the wax cells become smaller and the mass ratio of silk fibers to wax substance increases (Hepburn and Kurstjens, 1988). The smaller cells result in deficient bee production; due to the defect of space and a consequent shortage of food, honeybee larvae have to moult untimely to the prepupal stage, or nurse bees have to cap the cells before larvae develop maximally (Abdellatif, 1965; Berry and Delaplane, 2001). Also, smaller cells in honey-storing combs should result in the lower storage capacity of honey.

Furthermore, many previous studies indicated that the usage of old combs parallels with the appearance of variety of comb diseases; for instance, chalkbrood (Koenig et al., 1986), American foulbrood (Gilliam, 1985) and nosema (Bailey and Ball, 1991) are more likely to occur in beehives with old combs. Also, older combs appear to contain more brood pheromones, which can prevent the queens from laying eggs because they regard that cells are already used (Free and Winder, 1983). Otherwise, cells with small diameter in old combs may have a negative impact on the queen's egg-laying efficiency (Berry and Delaplane, 2001).

Nevertheless, many beekeepers are reluctant to regularly replace old wax combs and believe that such a 
practice is not economical because a comb contains about $1200 \mathrm{~g}$ of wax, and because the energy or resource required to construct a comb can be tantamount to $7.5 \mathrm{~kg}$ of honey (Seeley, 1985). Thus, balancing the positive versus negative sides of using older combs may be important for beekeepers to maximize honey production.

Here we conducted a series of investigations to elucidate the advantages and disadvantages of using wax combs for a long time. For this purpose, we examined some morphological and biological characteristics of honeybee workers produced from brood combs of different age.

\section{MATERIALS AND METHODS}

\section{Apiary studies}

This study was carried out in 2018 at the apiary of the Faculty of Agriculture, Kafrelsheikh University, Egypt, to evaluate the effect of different comb wax ages on brood areas, honey production, and some of the exterior and the interior organs of honey bee workers. Data collected from twelve colonies, each of which had seven combs with different wax ages (from 0 to 7 years old). Colonies were at the same-strength with about 10000 individuals of Carniolan honeybees Apis mellifera carnica.

\section{Wax comb measurements 1}

Ten square inches of a wax comb were collected and weighted using a sensitive balance. This collection and measurement was made using all the eight combs of different age from each test colony. The exuviae were also collected from each comb and weighted. The volume of the hexagonal cell (ml) was determined by measuring the water volume filled in each cell. The length of the inner cell diameter ( $\mathrm{mm}$ ) and the height of hexagonal cell base (mm) were also measured and recorded. These measurements were repeated in 20 cells for each wax comb collected. Thus, measurements were obtained from seven combs with different age collected from 12 colonies.

\section{Morphometric characters}

Morphometric measurements of eleven characteristics of the exterior and interior organs of honeybees were assessed using honeybee workers emerging from combs with different age. Newly emerged bees were obtained by bagging wax combs with bee cocoons. When honeybees emerged, they were collected and used for the following examination.

\section{(A): Weight of newly emerged honeybee workers}

25 honeybees collected were individually placed at $0^{\circ} \mathrm{C}$ for $5 \mathrm{~min}$ for paralysis and were then weighed using a sensitive balance.

\section{(B): Morphometric measurements}

The 25 honeybee workers after weighing were used to determine the areas of tibia and forewings, and the length of proboscis. The areas of the mandibular glands, the second wax glands, and one lobe of the hypopharyngeal glands were also measured.

The exterior characterers were measured using a scan photo method (SPM) by connecting a photoshop software and a scanner unit to a personal computer, according to the method of El-Aw et al. (2012). The scanner unit was used to take the image, and the image was then saved on the computer. The photoshop program was used to take the measure in $\mathrm{mm}$.

To examine the interior characters, the bee workers were kept in $75 \%$ alcohol, and were then dissected under a stereomicroscope (Nikon SMZ 745T) equipped with a Nikon DS Series Digital camera in order to measure the size (areas) of selected interior organs.

\section{Biological activities of honeybee workers}

\section{A) Brood rearing, workers and drones}

Brood rearing activity was assessed for combs of different age. For this purpose, areas of brood rearing in each comb were examined. Type of brood, i.e., workers or drones, was checked and total areas used for rearing the two brood types were measured in square inch every twelve days during the study.

\section{B) Honey yield}

Framed combs from each age group were collected to extract the honey that hey contained. Total honey yields were evaluated for each age group. Yield estimation was made in the end of May.

\section{Statistical analysis}

Data were analyzed using SPSS program (2006) in one way ANOVA. Spearman's correlation coefficient was used to detect the correlation between parameters.

\section{RESULTS}

\section{Influence of comb age on comb characters}

Comb characters differed markedly among combs of different age. The volume of hexagonal cell/ (ml) and the inner cell diameter ( $\mathrm{mm}$ ) were significantly different among the 7 comb age groups $(\mathrm{F}=1552.8, \mathrm{p}<0.001$ for cell; $\mathrm{F}=1059.2, \mathrm{p}<0.001)$, and these values were lower in older wax combs (Table 1), The exuvium weight (mg), the weight of wax square inch (gm) and the height of hexagonal cell base (mm) differed among the comb groups ( $\mathrm{F}=46711.9, \mathrm{p}<0.001$ for exuvium; $\mathrm{F}=4538.3$, $\mathrm{p}<0.001$ for wax square inch; $\mathrm{F}=1425.8, \mathrm{p}<0.001$ for cell base), and these values were higher in older combs (Table 1).

\section{Impact of wax comb age on workers organs}

Comb age had a great impact on the size of emerging honeybee workers. The weight of newly emerged honeybee workers was significantly higher in younger combs than in older combs $(F=10303.7, p<0.001)$. The workers emerged from younger combs had a longer proboscis $(\mathrm{F}=68.12, \mathrm{p}<0.001)$, larger of tibia $(\mathrm{F}=24.29$, $\mathrm{p}<0.001)$, larger tarsus $(\mathrm{F}=23.64, \mathrm{p}<0.001)$, and larger forewings $(\mathrm{F}=62.17, \mathrm{p}<0.001)$ than those from 
Table 1. Characteristics of wax combs in relation to wax ages

\begin{tabular}{|c|c|c|c|c|c|c|c|c|}
\hline \multirow{2}{*}{ Parameters } & \multicolumn{8}{|c|}{ Age of comb } \\
\hline & Zero year & One year & 2 years & 3 years & 4 years & 5 years & 6 years & 7 years \\
\hline $\begin{array}{l}\text { Weight of square inch of } \\
\text { comb (gm) }\end{array}$ & $1.69 \pm 0.08$ & $2.13 \pm 0.01$ & $3.84 \pm 0.12$ & $5.69 \pm 0.09$ & $6.13 \pm 0.06$ & $6.73 \pm 0.23$ & $7.53 \pm 0.21$ & $8.51 \pm 0.00$ \\
\hline $\begin{array}{l}\text { Volume of hexagonal cell } \\
\text { (ml) }\end{array}$ & $0.31 \pm 0.00$ & $0.24 \pm 0.00$ & $0.23 \pm 0.00$ & $0.22 \pm 0.01$ & $0.21 \pm 0.00$ & $0.20 \pm 0.00$ & $0.18 \pm 0.00$ & $0.16 \pm 0.00$ \\
\hline Exuviae weight (gm) & $0.00 \pm 0.00$ & $0.04 \pm 0.00$ & $0.05 \pm 0.00$ & $0.06 \pm 0.00$ & $0.08 \pm 0.00$ & $0.09 \pm 0.00$ & $0.10 \pm 0.00$ & $0.11 \pm 0.00$ \\
\hline Inner cell diameter (mm) & $6.00 \pm 0.00$ & $5.99 \pm 0.03$ & $5.81 \pm 0.07$ & $5.44 \pm 0.14$ & $4.96 \pm 0.05$ & $4.89 \pm 0.03$ & $4.86 \pm 0.06$ & $4.80 \pm 0.09$ \\
\hline $\begin{array}{l}\text { height of hexagonal cell } \\
\text { base (mm) }\end{array}$ & $0.39 \pm 0.07$ & $0.77 \pm 0.09$ & $1.22 \pm 0.08$ & $1.74 \pm 0.13$ & $2.03 \pm 0.13$ & $3.39 \pm 0.26$ & $4.00 \pm 0.26$ & $4.1 \pm 0.19$ \\
\hline
\end{tabular}

Table 2. Measurements of some exterior and interior organs of honeybee workers in different comb wax ages

\begin{tabular}{|c|c|c|c|c|c|c|c|}
\hline \multirow{2}{*}{ Parameters } & \multicolumn{7}{|c|}{ Age of comb } \\
\hline & One year & 2 years & 3 years & 4 years & 5 years & 6 years & 7 years \\
\hline $\begin{array}{l}\text { Weight of newly emerged workers } \\
\text { (mg) }\end{array}$ & $122.89 \pm 0.68$ & $107.68 \pm 0.68$ & $97.08 \pm 0.97$ & $87.08 \pm 1.09$ & $76.22 \pm 1.47$ & $71.33 \pm 1.63$ & $68.06 \pm 1.41$ \\
\hline Length of proboscis (mm) & $5.91 \pm 0.20$ & $5.64 \pm 0.09$ & $5.58 \pm 0.11$ & $5.00 \pm 0.43$ & $4.93 \pm 0.52$ & $4.55 \pm 0.591$ & $4.26 \pm 0.263$ \\
\hline Area of tibia $\left(\mathrm{mm}^{2}\right)$ & $2.83 \pm 0.45$ & $2.38 \pm 0.25$ & $2.34 \pm 0.26$ & $2.25 \pm 0.20$ & $2.16 \pm 0.17$ & $2.13 \pm 0.26$ & $1.95 \pm 0.27$ \\
\hline $\begin{array}{l}\text { Area of basal segment of tarsus } \\
\left(\mathrm{mm}^{2}\right)\end{array}$ & $2.41 \pm 0.03$ & $2.30 \pm 0.04$ & $2.36 \pm 0.04$ & $2.14 \pm 0.02$ & $2.09 \pm 0.02$ & $2.04 \pm 0.02$ & $1.98 \pm 0.03$ \\
\hline Area of fore wings $\left(\mathrm{mm}^{2}\right)$ & $18.03 \pm 0.48$ & $17.77 \pm 0.61$ & $17.57 \pm 0.73$ & $17.45 \pm 0.59$ & $16.82 \pm 1.16$ & $15.30 \pm 0.90$ & $14.18 \pm 1.48$ \\
\hline Area of mandibular glands $\left(\mathrm{mm}^{2}\right)$ & $1.63 \pm 0.28$ & $1.52 \pm 0.22$ & $1.37 \pm 0.37$ & $1.05 \pm 0.19$ & 1.010 .37 & $0.83 \pm 0.25$ & $0.81 \pm 0.25$ \\
\hline $\begin{array}{l}\text { Area of one lobe of hypopharyngeal } \\
\text { glands }\left(\mathrm{mm}^{2}\right)\end{array}$ & $0.06 \pm 0.01$ & $0.03 \pm 0.00$ & $0.026 \pm 0.04$ & $0.02 \pm 0.04$ & $0.01 \pm 0.00$ & $0.01 \pm 0.00$ & $0.01 \pm 0.00$ \\
\hline $\begin{array}{l}\text { Area of the second wax gland } \\
\left(\mathrm{mm}^{2}\right)\end{array}$ & $3.12 \pm 0.29$ & $2.99 \pm 0.27$ & $2.90 \pm 0.24$ & $2.80 \pm 0.31$ & $2.69 \pm 0.16$ & $2.07 \pm 0.20$ & $1.85 \pm 0.13$ \\
\hline
\end{tabular}

older combs (Table 2). The areas of mandibular glands $(\mathrm{F}=42.47, \mathrm{p}<0.001)$, one lobe of hypopharyngeal $(\mathrm{F}=$ $17.17, \mathrm{p}<0.001)$ and the second wax gland $(\mathrm{F}=99.04$, $\mathrm{p}<0.001$ ) were bigger when bee worders emerged from younger combs (Table 2 ).

\section{Influence of comb age on workers biological activ- ities}

The total brood areas for rearing worker bees were about 105, 52, 45, 42, 40, 37, and 30 inch $^{2}$ for one, two, three, four, five, six, and seven years old combs, respectively. The total workers brood area decreased significantly as the comb age increased $(\mathrm{F}=19.14, \mathrm{p}<0.01)$ (Fig. 1). The drone brood areas were about 6, 3.5, 1.6, $2.9,2,2.5$, and $1.8 \mathrm{inch}^{2}$ for one, two, three, four, five, six, and seven years old combs, respectively. Total drones brood areas also were significantly lower in older combs ( $\mathrm{F}=2.7, \mathrm{p}<0.01$ ) (Fig. 1).

The average honey yields in the first year of comb age was $2.62 \mathrm{~kg}$ and decreased gradually to be $1.72 \mathrm{~kg}$ for the seven-years combs. Total honey yields were signifi- cantly lower in loder combs $(\mathrm{F}=38312.2, \mathrm{p}<0.001)$ (Fig. 2).

\section{Relationships between cell volume and honeybee morphometrics}

Lastly, we examined the relationships between comb age and emerging honeybee workers. To do so, the mean volume of hexagonal cells was used as an index reflecting comb age. Positive correlations were noticed between the volume of hexagonal cells and workers' body weight $(r=0.961, \mathrm{n}=7, \mathrm{p}<0.01)$, proboscis length $(r=0.933, \mathrm{n}=7, \mathrm{p}<0.01)$, area of tibia $(r=$ $0.994, \mathrm{n}=7, \mathrm{p}<0.01)$, the area of basal segment of hind tarsus $(r=0.913, \mathrm{n}=7, \mathrm{p}<0.01)$, the area of forewings $(r=0.837, \mathrm{n}=7, \mathrm{p}<0.05)$, the area of mandibular glands $(r=0.923, \mathrm{n}=7, \mathrm{p}<0.01)$, the area of one lobe of hypopharyngeal $(r=0.934, \mathrm{n}=7, \mathrm{p}<0.01)$, and the area of the second wax gland $(r=0.864, \mathrm{n}=7, \mathrm{p}<$ $0.05)$. 


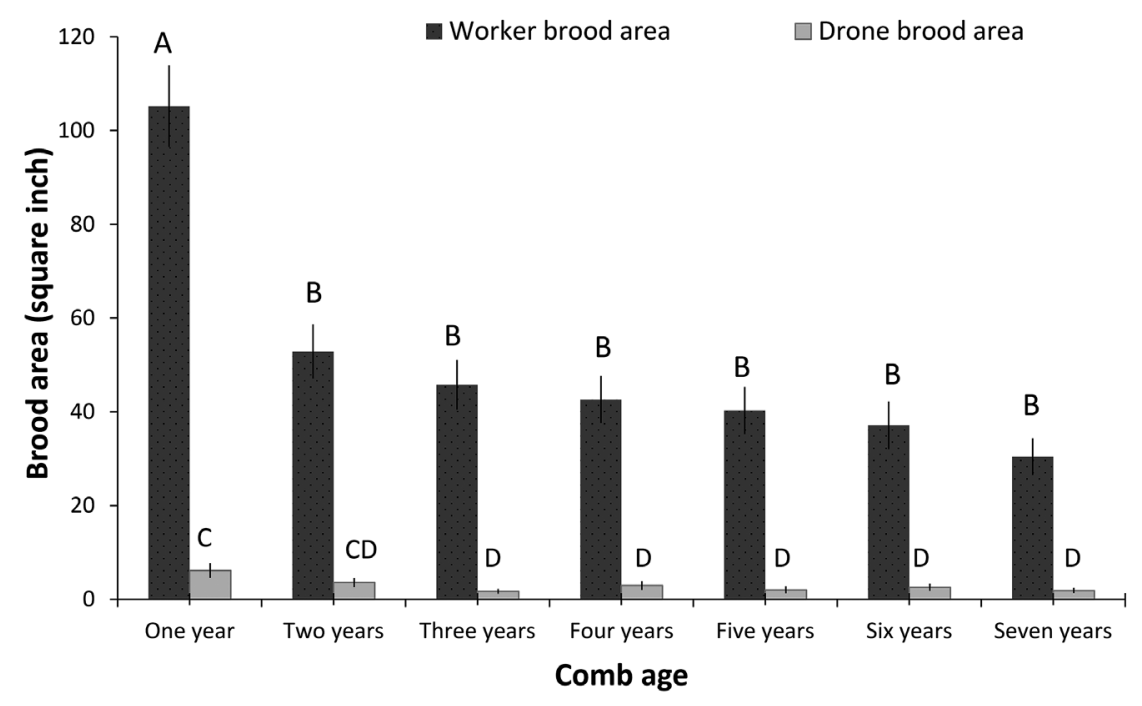

Fig. 1. Relationships between brood areas and comb age. Means $\pm \mathrm{SE}$ are shown. Different letters above bars indicate significant difference (Tukey's HSD test, $P<0.05$ ).

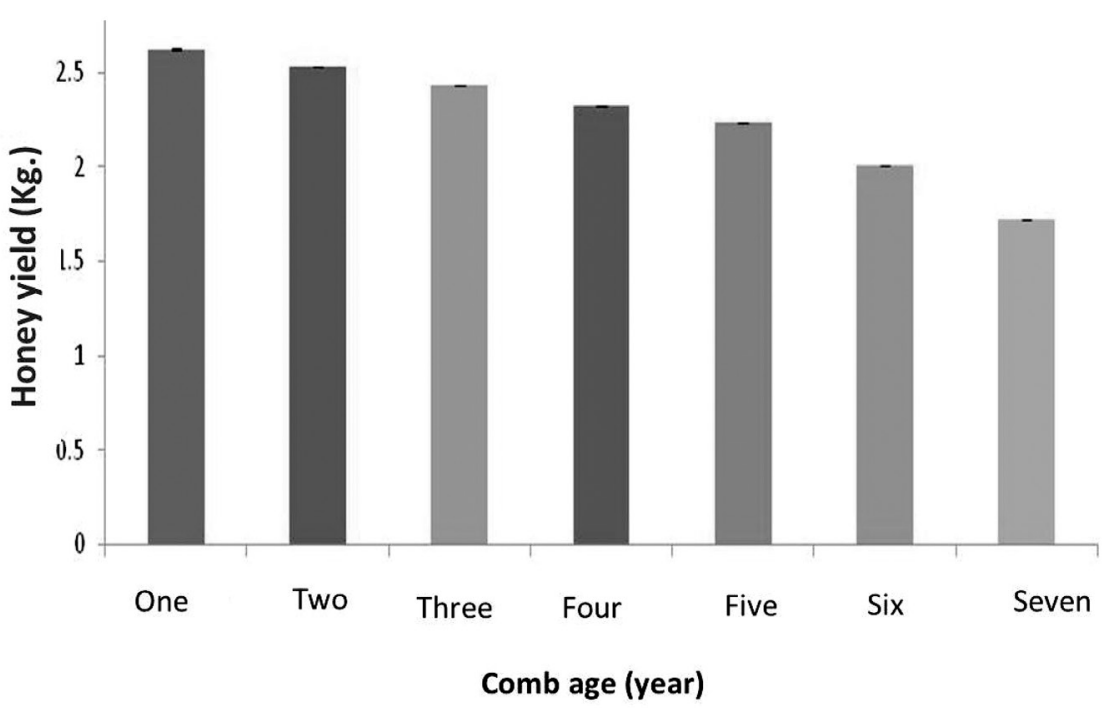

Fig. 2. Average of honey yields at different wax comb ages. Means $\pm \mathrm{SE}$ are shown. Statistical details are in the Results.

\section{DISCUSSION}

The present study has revealed that the cell diameter and volume become smaller in older combs whereas the weight of exuviae and the height of hexagonal cell base are greater in older combs (Table 1). The present results agree with Berry and Delaplane (2001), Hepburn and Kurstjens (1988), and Jay (1963). These previous studies documented that the diameter of the cell became smaller as brood rearing repeated because developing larvae left their exuviae and silks in the hexagonal cell. The present study also showed that the comb weights increased with comb age (Table 1). An increase of comb weights can, at least in part, be explained by accumula- tions of such exuviae and silks produced by honeybee larvae as Hepburn and Kurstjens (1988) suggested. An accumulation of debris and propolis may also be a factor resulting in the increase of comb weights (Koenig et al., 1986).

Importantly, Abdellatif (1965) and Berry and Delaplane (2001) have stressed that when cell diameter or volume is smaller, the body of honeybees is smaller because of the space limitation and the relative reduction of food. In addition, small cells may obligate larvae to pupate before they grow enoughtly (Abdellatif, 1965), resulting in production of smaller honeybee workers. In the present study, we confirmed that the size of honeybee workers, indexed by body weight, forewing size, etc., 
decreased with increasing comb age (Table 2). We also demonstrated that highly positive correlations between cell volume and bee size (see the Results). Our study, thus, highlights the importance of comb age or cell volume in determining the size of emerging honeybee workers.

We showed that total brood area was significantly smaller in older combs. The results agreed with Abdellatif (1965) who revealed that egg-laying and sealed brood area were better in new combs. The queens can discriminate between drone cells and worker cells by estimating the width of the hexagonal cells with their forelegs before oviposition (Koeniger, 1970). Therefore, smaller cells in older combs, which are smaller, should have a negative impact on egg laying responses by the queen (Berry and Delaplane, 2001), which may eventually result in a lower production rate of honeybee workers and drones in older combs.

It is widely suggested that old and dark wax combs contain many contaminants and pesticide residuals, which may be harmful to the health of honeybee brood. Koenig et al. (1986) indicated that old combs have been related with an increased occurrence of chalkbrood. Similarly, some other diseases such as American foulbrood and nosema, which can spread easily from one colony to another by infected wax combs, are more likely to be detected in colonies with older combs (Gilliam, 1985; Bailey and Ball, 1991). The queens may recognize the presence of such pollutants, and may not lay eggs in "dirty" cells. Free and Winder (1983) found that old wax combs might contain pheromones of brood, which could inhibit the oviposition by queens because they would regard many cells in the combs had already been occupied by developing larvae. Our present study has also confirmed this; brooding areas for workers and drones were evidently smaller in older combs (Fig. 1). Thus, the present and previous studies strongly suggest that older combs have numerous negative effects on honeybee health and reproduction.

The process of nectar collection and honey production depends on many environmental and physiological factors. For example, the availability of nearby flowering plants has a great impact on honey yields (Shawer et al., 2019). The size of bees and wasps is known to have a variety of influences associated with longevity, reproduction, and behavior (Ueno, 1999a, b; Ueno and Ueno, 2005). Likewise, the morphology of honeybee workers like body size, proboscis length, and area of corbicula can affect foraging activity, efficiency and nectar collection (Al-Buraki and Al-Buraki, 2008). The length of proboscis of bee worker plays an important role in nectar collection because it can determine the capability of the bees to reach nectar glands that may be present deep inside the flowers (Mostajeran et al., 2006). Corbicula size and fore- or hind-wing area have a positive correlation with the production of the honey (Szabo, 1990). Wing morphometry affects the flight ability of honeybee workers (Horomitz, 1983). Thus, a reduction of cell size in older combs should have a negative consequence on honey yields through its negative impact on honeybee workers. In fact, in the present study, we have demonstrated that bee morphology show a variety of negative effects when honeybee workers emerged from old combs (Table 2). Further, we have shown that honey yields are lower in older combs (Fig. 2).

It can thus be concluded that cell size is smaller in older combs, and this in turn results in production of fewer and smaller honeybee workers, which eventually leads to a decrease of total honey yields. Since new wax combs improve the honeybees colony health and reproduction, it can be recommended that beekeepers should remove very old wax combs from their bee colonies and replace them to new ones.

\section{ACKNOWLEDGEMENTS}

The authors would like to acknowledge Dr. Shamel M. Alam-Eldein, a senior lecturer of Pomology, Faculty of Agriculture, Tanta University for the proofreading of this manuscript. Also, thanks are due to Dr. Ahmed Saad-Eldein Elkhodary, a professor of Entomology, Faculty of Agriculture, Kafrelsheikh University, for his valuable comments.

\section{AUTHOR CONTRIBUTIONS}

M. B. Shawer, E. M. Elnabawy, K. M. Mousa and Sahar Gaber designed the experiments, conducted the field study, analyzed the data, wrote the initial draft of the manuscript and contributed in discussion. T. Ueno discussed the results and polished up the research concept and manuscript. All authors read and approved the final manuscript.

\section{CONFLICT OF INTEREST}

The authors declare no conflicts of interest.

\section{REFERENCES}

Abdellatif, M. A. 1965 Comb cell size and its effect on the body weight of the worker bee, Apis mellifera L. Am. bee J., 105: 86-87

Al-Buraki, M. and A. Al-Buraki 2008 Morphometrical study on Syrian honey bee (Apis mellifera syriaca). Emir. J. Food Agric., 20: 89-93

Bailey, L. and B. V. Ball 1991 Honeybee pathology. Harcourt Brace Jovanovich; Sidcup, Kent, UK

Berry, J. A. and K. S. Delaplane 2001 Effects of comb age on honey bee colony growth and brood survivorship. J. Apic. Res, 40: $3-8$

D'ettorre, P., T. Wenseleers, J. Dawson, S. Hutchinson, T. Boswell and F. Ratnieks 2006 Wax combs mediate nestmate recognition by guard honeybees. Anim. Behav., 71: 773-779

Dizaji, A. A., H. M. Alishah, A. A. Shanddel and N. M. Sis 2008 Effects of comb wax age on the brood and honey product performance in honey bee. Asian J. Anim. Vet. Adv., 3: 51-53

El-Aw, M., K. Draz, K. Eid and H. Abo-Shara 2012 Measuring the morphological characters of honey bee (Apis Mellifera L.) using a simple semi-automatic technique. J. Am. Sci., 8: 558564

Free, J. B. and M. E. Winder 1983 Brood recognition by honeybee (Apis mellifera) workers. Anim. Behav., 31: 539-545

Gilliam, M. 1985 Microbes from apiarian sources: Bacillus spp. in 
frass of the greater wax moth. J. Invertebr. Pathol., 45: 218224

Hepburn, H. R. and S. P. Kurstjens 1988 The combs of honeybees as composite materials. Apidologie, 19: 25-36

Horomitz, R. F. A. 1983 Inbreeding effects in flight muscle mitochonidria of Apis mellifera. Rev. Brasil. Genet., 6: 59-70

Jay, C. S. 1963 The development of honeybees in their cells. J. Apic. Res., 2: 117-134

Karihaloo, B.L., K. Zhang and J. Wang 2013 Honeybee combs: how the circular cells transform into rounded hexagons. J. $R$. Soc. Interface, 10: 20130299

Koenig, J. P., G. M. Boush and E. H. Erickson 1986 Effect of type of brood comb on chalk brood disease in honeybee colonies. $J$. Apic. Res., 25: 58-62

Koeniger, N. 1970 Factors determining the laying of drone and worker eggs by the queen honeybee. Bee World, 51: 166-169

Mostajeran M. A., M. A. Edriss and M. R. Basiri 2006 Analysis of colony and morphological characteristics in honey bees (Apis mellifera meda). Pak. J. Biol. Sci., 9: 2685-2688

Seeley, T. D. 1985 Honeybee Ecology. Princeton University Press; Princeton, NJ, USA, 201 pp

Seeley, T. D. and R. A. Morse 1976 The nest of the honey bee
(Apis mellifera L.). Ins. Soc., 23: 495-512

Shawer, M. B., O. M. Rakha, E. M. Elnabawy, A. A. Elashmawy and T. Ueno 2019 Banana flowers (Musa sp.: Musaceae): an essential source of nectar for honeybee during the dearth period in Egypt. J. Fac. Agric., Kyushu Univ., 64: 79-85

SPSS 2006 SPSS15.0 for Windows. SPSS Inc. Chicago, IL

Szabo, T. I. 1990 Morphometric characteristics of Apis cerana from Sri Lanka, Apidologie, 21: 505-509

Taha, E. A. and S. Y. EL-Sanat 2007 Effect of combs age on honey production and its physical and chemical properties. Proc. $2^{\text {nd }}$ Int. Conf. Entomol. Soc. Egypt, 11: 9-18

Ueno, T. 1999a Host-size-dependent sex ratio in a parasitoid wasp. Res. Popul. Ecol., 41: 47-57

Ueno, T. 1999b Adult size and reproduction in the ectoparasitoid wasp Agrothereutes lanceolatus Walker (Hymenoptera, Ichneumonidae). J. Appl. Entomol., 123: 357-361

Ueno, K. and T. Ueno 2005 Effect of wasp size, physiological state and prior host experience on host searching behavior in a parasitoid wasp (Hymenoptera: Ichneumonidae). J. Ethol., 23: 43-49

Winston, M. L. 1991 The Biology of the Honey Bee. Harvared Univ. Press, Harvard, 281 pp 